June 2003

\title{
Declining Required Reserves, Funds Rate Volatility, and Open Market Operations*
}

\begin{abstract}
The standard view of the monetary transmission mechanism rests on the central bank's ability to manipulate the overnight interest rate by controlling reserve supply. In the 1990s, there was a significant decline in the level of reserve balances in the U.S. accompanied at first by an increase in the funds rate volatility. However, following this initial rise, volatility declined. In this paper, we find evidence of a structural break in volatility. We then estimate a tobit model of the major types of temporary open market operations and conclude that there have been changes in the Desk's reaction function that played a major role in controlling volatility.
\end{abstract}

JEL Classification Codes: E0, E4, E5

Keywords: Required Reserves, Open Market Operations, Trading Desk

Selva Demiralp

Board of Governors of the Federal Reserve

System

Division of Monetary Affairs

Washington, DC 20551

e-mail: selva.demiralp@frb.gov
Dennis Farley

Board of Governors of the Federal Reserve

System

Division of Monetary Affairs

Washington, DC 20551

e-mail: dennis.e.farley@frb.gov

*We would like to thank Sherry Edwards, Spence Hilton, David Lindsey, William Whitesell, James Hamilton, Oscar Jorda and the conference participants of the II Meeting of Open Market Technicians for valuable comments. Heather McNett and Heather Wiggins provided excellent research assistance. The views expressed are those of the authors and do not necessarily reflect the views of the Board of Governors or other members of its staff. 


\section{Introduction}

Monetary policy is implemented on a daily basis primarily through open market operations. Carried out by the Trading Desk at the Federal Reserve Bank of New York, open market operations are the main tool for bringing the supply of balances at the Federal Reserve in line with the demand at an interest rate near the level specified by the Federal Open Market Committee (FOMC). These purchases and sales of U.S. government securities determine the supply of reserves available and, given demands for reserves, determine the federal funds ratethe interest rate at which depository institutions lend balances at the Federal Reserve to each other overnight. Movements in the funds rate then affect the real economy through the monetary or credit channels of the monetary transmission mechanism.

Over time, the conduct of open market operations has had to adapt to structural changes in the supply of, or demand for, reserve balances. One such change has been the gradual decline in reserve requirements since the early 1990s, leading to lower demands for Federal Reserve balances, and in this paper, we investigate the Desk's response to this development. Our findings suggest that in an environment of low required balances, the Desk has tailored its operations to address the new demand pattern that has emerged in the banking system, thereby limiting the size of deviations of the funds rate from the FOMC target.

The remainder of the paper is organized as follows: Section 2 discusses the implications of lower reserve requirements for volatility in the federal funds rate and the implementation of open market operations. Section 3 examines the decline in funds rate volatility despite lower reserve requirements and looks for a structural break in volatility. Section 4 describes the types of open market operations we are considering and explains the methodology that is used measure the Desk's reaction function. Section 5 provides empirical evidence of changes in the Desk's reaction function. Section 6 concludes. 


\section{Declining Demand for Reserve Balances and Open Market Operations}

A depository institution satisfies its reserve requirement with vault cash and the balance maintained in its account at a Federal Reserve Bank. As shown in Figure 1, total required balances (the solid line) trended down in the 1990s because of a decline in required reserve balances - the area between the solid line and the lower dashed line. The decline in required reserve balances reflected official actions and private sector activity. In December 1990, the required reserve ratio on Eurocurrency liabilities and on nontransaction deposits was reduced in two steps from 3 percent to zero. In April 1992, the ratio for transaction deposits was reduced from 12 percent to 10 percent. Beginning in 1994, depository institutions adopted retail sweeps programs in which funds above a predetermined amount are transferred from a depositor's checking account on which required reserve ratios are positive, to nontransaction accounts, a special purpose MMDA, which is not reservable (see Anderson and Rasche, 2000). Since 2000, monetary policy easing has caused required reserve balances to rebound somewhat, owing to an upsurge in transaction deposits in an environment of low opportunity costs.

The 1990s also saw an expansion of required clearing balances (the lower dashed line), which pay implicit interest in the form of earnings credits that are used to defray the costs of Federal Reserve services. As declining required reserve balances left some institutions with insufficient protection against overnight overdrafts, these institutions established or expanded clearing balances, as seen in Figure 1. A more detailed discussion of the decline in required reserve balances and the response of required clearing balances can be found in Edwards (1997). In recent years, required clearing balances have also expanded. As the federal funds rate has fallen, depository institutions have needed to hold more clearing balances to pay for a given level 
of service. $^{-1}$ Excess balances, the difference between the solid line and the top broken line (total operating balances) in Figure 1, have not varied much over the sample shown, except for the period right after September 11, 2001. As a result, total balances at the Federal Reserve have reflected the net downward trend in required balances over the 1986-2002 period.

Institutions accounting for the great bulk of required balances satisfy their balance requirement on average over a two-week maintenance period. The ability to average holdings of balances over the days of a maintenance period gives depository institutions considerable flexibility in managing their accounts from day to day. This flexibility limits the volatility in rates that can develop when the Desk misestimates either the supply of, or demand for, balances. Thus, if the funds rate is soft on a given day, depository institutions may hold higher levels of excess balances, preventing a further decline in the rate. They can offset the surplus by holding lower balances on subsequent days and still satisfy their requirements. In fact, for the period from March 1984 to November 1990, Hamilton (1996) provides empirical evidence that depository institutions did exploit arbitrage opportunities in the funds market and that the funds rate exhibited a "near-martingale" behavior, with market frictions such as line limits, transaction costs, and weekend accounting conventions preventing a perfect random walk.

When required balances are low relative to balances needed for clearing, however, the ability of depository institutions to substitute balances across days of the maintenance period is limited. A bank is less likely to hold a balance above its total balance requirement because its ability to target lower balances on subsequent days is constrained by the balance it must hold to avoid an overnight overdraft. Therefore, it will seek to lend any extra balances, on which it earns no interest, even if the funds rate is low. It is less likely to tolerate a balance below its total

\footnotetext{
${ }^{1}$ Earnings credits are calculated by multiplying the average effective federal funds rate by the average end-of-day clearing balance maintained during a particular maintenance period.
} 
required balance as well, because it is more likely to run an overdraft. Hence, it will try to borrow balances, even if the funds market is tight (see Edwards, 1997).

In addition to limiting the exploitation of arbitrage opportunities, lower balance requirements can increase the daily volatility of end-of-day balances at the Federal Reserve as payment-related demand for balances exceeds demand to meet balance requirements. Paymentrelated demand is a precautionary demand that must be met each day, and the magnitude of that demand depends on the size and timing of payment flows through an institution's Federal Reserve account, which can be highly variable and uncertain (see Furfine, 2000). As a result, a depository institution's targeted end-of-day Federal Reserve balance can vary dramatically over the days of a maintenance period. Further contributing to funds rate volatility is the fact that such payment-related demand tends to be less interest elastic (see Clouse and Elmendorf, 1997).

Despite the decline in total required balances, most measures show that funds rate volatility increased only somewhat during a few brief episodes over the last decade. As illustrated in Figure 2, the mean absolute deviation of the daily effective federal funds rate from target did increase in 1991, following the cuts in reserve ratios, and again in 1996, the year when the proliferation of sweep programs was at its height, but funds rate volatility has since tapered off. The average effective and average morning funds rate deviations from the target, displayed in Figure 3, also show a downward trend over the sample although they have fluctuated in rather limited ranges around zero over the last decade. Figure 4 shows that the spread between the daily high and daily low funds rates, and the intraday standard deviation of brokered federal funds trades did not increase after 1996 and has fallen further in the past few years. ${ }_{\text {The main }}$

\footnotetext{
${ }^{2}$ Intraday standard deviation is a volume-weighted measure of standard deviation, based on total brokered funds rate transactions on a given day.
} 
argument of this paper is that Desk actions have been an important contributor to the declines in volatility shown in Figures 2 through 4.

\section{A Structural Change in the Volatility of the Federal Funds Rate}

This section tries to identify a structural break in funds rate volatility at business day

frequency. We use the two measures in Figure 4, the daily high-low range and intraday standard deviation to perform structural break tests. We rely on several tests proposed in Bai and Perron (1998) for estimating a priori unknown structural break dates. The estimation problem is solved with an efficient algorithm that computes the global minimizers of the sum of squared residuals. In particular, we consider the following regression where the dependent variable $y_{\tau}$ - which is the measure of volatility_is regressed onto a constant with $m$ breaks ( $m+1$ regimes):

$$
y_{\tau}=\alpha_{j}+u_{\tau} \quad \tau=T_{j-1}+1, \ldots, T_{j}
$$

for $j=1, \ldots, m+1$. The break points $T_{1}, \ldots, T_{m}$ are unknown (by convention, $T_{0}=0$ and $T_{m+1}=$ $T$, and the goal is to estimate the unknown coefficients $\left(\alpha_{1}, \ldots, \alpha_{m} ; T_{1}, \ldots, T_{m}\right)$ assuming $\alpha_{j} \neq \alpha_{j+1}, 1 \leq j \leq m$. For each $m$-partition, the associated least squares estimates are obtained by minimizing the sum of squared residuals,

$$
S_{T}=\sum_{j=1}^{m+1} \sum_{\tau=T_{j-1}+1}^{T_{j}}\left[y_{\tau}-\alpha_{j}\right]^{2}
$$

Then, the estimated break points are

$$
\left(\hat{T}_{1}, \ldots, \hat{T}_{m}\right)=\arg \min _{T_{1}, \ldots, T_{m}} S_{T}\left(T_{1}, \ldots, T_{m}\right)
$$

where the minimization is taken over all partitions $\left(T_{1}, \ldots, T_{m}\right)$ such that $T_{j}-T_{j-1} \geq q$. Bai and Perron (1998) develop sup Wald type tests for the null hypothesis of no change versus an arbitrary number of changes, as well as the null hypothesis of $l-1$ changes against the 
alternative of $l$ changes. Their recommended strategy is to use the first type of sup Wald test to determine whether or not breaks are present and then use a sequential application of the second type of sup Wald test to determine the number of breaks.

The results of these tests are reported in the upper panel of Table 1. We constrain the maximum number of breaks to be one and allow for serial correlation in the error terms. We choose the minimum size partition to be 20 percent of the total sample size $T$, such that $q=T / 5$. For each volatility measure, the upper panel contains the sup $F(1 \mid 0)$ test for the null hypothesis of no breaks against the alternative of one break (see Bai and Perron, 1998 for details). The last column of the upper panel reports the dates selected by the global minimizer. The selection of the number of structural changes using Bai and Perron tests can be viewed as a specification problem for which information criteria can be used. The lower panel of Table 1 reports the number of breaks selected by two information criteria Liu, Wu, and Zidek (LWZ) and Schwarz's Bayesian information criterion (BIC), based on the dates selected by Bai and Perron tests. Complementary evidence derived from the asymptotically consistent information criterion is particularly essential in this case since the asymptotic properties of sup F tests may be susceptible to the fact that the dependent variable is an estimated measure of volatility.

The tests in Table 1 strongly suggest a break in the volatility of funds rate. As shown in the second and the third rows of the upper panel, the break dates selected by the global minimizers are very similar across the two volatility measures for the post-1994 sample, indicating a structural break in January $2000{ }^{\text {目 }}$ This result confirms our prior belief that the two series mimic each other very closely as indicators of funds rate dispersion. The full sample results using the high-low range suggest a somewhat earlier structural break in July 1999. While

\footnotetext{
${ }^{3}$ Data for intraday standard deviation is only available for the post-1994 sample.
} 
the two dates are not too far apart from each other, the results based on the larger sample are likely to be more precise.

The failure of funds rate volatility to rise, despite the decline in total required balances since the late 1980s, suggests that payment-related demands for balances generally remain below required balances plus frictional excess balances demanded, allowing intertemporal arbitrage to keep the funds rate relatively stable (see Edwards, 1997). Bennet and Peristani (2002) further note that because an increasingly larger proportion of banks fulfill their reserve requirements by

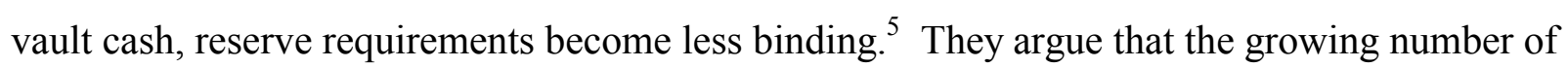
"unbound" banks — which are less likely to be concerned by settlement-day adjustments—-may have contributed to the reduction in funds market volatility. Several other developments may have played a role in bringing this about. Improvements in internal information systems, including those that track the balance in a bank's Federal Reserve account, and banking industry consolidation may have reduced uncertainty about payment flows. In addition, the switch from contemporaneous required reserves to lagged required reserves in July 1998 reduced uncertainty at the start of the maintenance period about the demand for required reserve balances and possibly has contributed to reduced funds rate volatility (see Federal Reserve Bank of New York Markets Group Annual Report, 2001). It should be noted that the decline in volatility for the past few years may also partly owe to the increase in total required balances.

\footnotetext{
${ }^{4}$ Structural break tests for this series are re-estimated for $m>1$. Under the assumption of multiple structural breaks, global optimizers chose an additional break date in June 1990, shortly before the surge in volatility later that year. We believe that this earlier break is largely driven by the cuts in reserve requirement ratios and do not call for an investigation of the underlying change in Desk behavior. Hence, for the purposes of this paper, we focus on the single structural break in volatility reported in the text. This simplification leaves us with sufficient degrees of freedom for the sub-sample analysis in the next section, without affecting the quality of our research.

${ }^{5}$ In early 1996, over 3,000 institutions had less vault cash than their required reserves, necessitating them to hold balances at the Federal Reserve (see Akhtar, 1997). As of April 30, 2003, there were merely 1719 such institutions, relative to 2600 institutions that only hold vault cash to meet their entire reserve requirements.
} 
On the supply side of the reserves market, changing Desk behavior has likely been crucial in controlling daily fluctuations in the funds rate in an environment of low total required balances. Having always taken account of maintenance period demands for required balances, the Desk now focuses more closely on ensuring that total balances at the Federal Reserve are sufficient to meet payment-related demands on a day-by-day basis. In recent years, the Desk has more assiduously targeted higher levels of excess balances on days with high payment flows in an attempt to discourage the upward rate pressures that historically are more prevalent on such days. Morning premiums on high payment flow days show a significant decline relative to past years, reflecting, at least in part, the impact of these efforts, as well as the effect of the general trend to lower volatility built into market expectations in recent years. Bartolini, Bertola, and Prati (2002) highlight that when the public's confidence in the Federal Reserve's commitment to the target is greater, deviations from the target rate tend to be smaller. The authors develop a theoretical model, which implies a decline in funds rate volatility, despite the decline in reserve requirements in 1990s. They argue that in an era of improved policy transparency and public announcements of target changes, the Desk is likely to undertake larger operations when needed, because these operations cannot be perceived as signals of policy shifts. Further contributing to the decline in volatility is that when target changes are less likely—as in post-1994 period, the Desk offsets most liquidity shocks rather than letting the rates follow market rates passively. Demiralp and Jorda (2003) find further evidence of an improvement in the Federal Reserve's control of market rates in the post-1994 era. In the remainder of this paper, we address these claims formally by estimating the Desk's reaction function. We aim to document such changes in behavior in response to changing conditions in the market for balances. Our results are 
strongly consistent with the findings in the earlier literature and their implications for Desk actions.

\section{Modeling Open Market Operations}

\subsection{Types of Operations}

Open market operations consist of outright and temporary purchases or sales of U.S. Government securities. Outright transactions typically accommodate changes in the Federal Reserve's balance sheet that are expected to endure, such as the growth in the stock of Federal Reserve notes. Temporary operations are designed to offset short-lived imbalances between the supply of and demand for balances. The Desk usually relies on short-term (mainly overnight) repurchase agreements $(R P \mathrm{~s})$ to address temporary shortages of balances that arise within a maintenance period. Overnight $R P$ s are well suited for fine-tuning the daily level of balances, especially on days with heightened payment-related demands. When balance needs are expected to persist for more than a maintenance period but eventually to reverse, the Desk relies on longterm $R P$ s (defined as those with maturities of sixteen calendar days or more). First used on a large scale in 1999 to meet reserve needs around the century-date-change, long-term $R P$ s, typically with a 28-day of maturity, have become routine. They are a convenient way to meet seasonal reserve swings, such as the year-end bulge in the demand for currency, and they provide a vehicle for adjusting balances over multiple maintenance periods until a permanent change in outright holdings is made.

The Desk also employs temporary draining operations, but these operations are far less frequent than $R P$ transactions because the Desk typically positions itself to add rather than drain balances over the maintenance period. The main reason for this strategy is that dealer 
participation is significantly lower in draining operations, reflecting dealers' net borrowing needs.

Until December 2002, temporary draining operations were implemented through matched sale-purchase transactions (MSPS), in which the Federal Reserve agreed to sell a short-dated security at a specified price and the buyer agreed to sell it back on a specific date. On December 13, 2002, the Federal Reserve Bank of New York implemented a new accounting system and replaced matched sale-purchase transactions with reverse repurchase agreements. Like MSP transactions, reverse $R P$ s drain balances from the banking system, but reverse repurchase agreements are more commonly used in financial markets. The Desk did not arrange any reverse $R P$ s with primary dealers in 2002; it conducted the first such operation on February 7, 2003 to address softness in the funds market.

In implementing daily open market operations, the Desk attempts to ensure that the supply of balances over a reserve maintenance period satisfies demand at a rate consistent with the FOMC's federal funds rate target. Each morning, members of the monetary projection staff at the Federal Reserve Bank of New York and their counterparts at the Board present to the Desk their estimates of the likely behavior of factors affecting balances. The estimated supply of balances without further open market operations is then compared with the goal for the period in order to develop a plan for operations (see Meulendyke, 1998, Chapter 6).

\footnotetext{
${ }^{6}$ While there were no reverse $R P$ s with primary dealers in 2002 , they were transacted daily with foreign official and international accounts starting December 13, 2002. Foreign central banks hold demand deposits at Federal Reserve Banks for execution of various dollar-denominated transactions. Because these customers cannot be paid interest on their deposits, the Federal Reserve maintains an overnight investment facility for these accounts known as the foreign $R P$ pool.
} 


\subsection{The Tobit Model}

If, over time, the Desk has focused more closely on daily balance needs, it ought to be reflected in an increased frequency of operations, particularly the number and volume of overnight repurchase agreements. The data in Table 2 are suggestive in this regard and point to a possible change in Desk operations in the second half of the 1990s, which ultimately led to a structural decline in the funds rate volatility by the end of the decade. Yet, despite the increased frequency of operations observed in Table 2, the Desk does not engage in even the most frequent (overnight) $R P$ operations more than fifty percent of the time. For this reason, we cannot use ordinary estimators for the Desk's choice of operations because the dependent variable remains unchanged during most days in the sample period. Feinman (1993) addressed this problem by estimating a multinomial logit model among different operation types. The inherent problem with this approach is that the alternatives in a multinomial logit model are assumed to be mutually exclusive. In the context of choice between different types of open market operations, this assumption is rather restrictive in the current framework, given the treatment of these operations as complementary rather than substitute tools to address a specific reserve need. Indeed, in a recent paper Hilton (2003) characterizes the Desk's choice of long-term $R P$ s as a function of expected short-term $R P \mathrm{~s}$ that are planned for the maintenance period, providing a strong argument against the treatment of different operations as mutually exclusive.

As an alternative estimation strategy, we model each open market operation $i$ as a latent

variable, $y_{i}^{*}$, which is only observed when it exceeds a certain threshold, $t_{i}$ (see Demiralp and Jorda, 2002). The latent process for each short-term operation is a function of a vector of explanatory variables, $X_{i}$ : 


$$
\begin{aligned}
& y_{i}^{*}=X_{i}{ }^{\prime} \beta+\varepsilon_{i} \\
& y_{i}=0 \text { if } y_{i}^{*} \leq t_{i} \\
& y_{i}=y_{i}^{*} \text { if } y_{i}^{*}>t_{i}
\end{aligned}
$$

Under the assumption that the error terms are normally distributed, $\varepsilon_{i} \sim N\left(0, \sigma^{2}\right)$, the regression model based on this framework can be estimated as a standard tobit model (also known as a censored regression model). Equation 4 indicates that the minimum size of an operation of the $i^{\text {th }}$ type is $t_{i}$. By allowing alternative operation types $j, j \neq i$, to affect the levels of the explanatory variables for operation type $i$, this specification captures the complementary nature of open market operations.

\subsection{Interpretation of the Estimated Tobit Model}

There are three regression functions associated with a standard tobit model (see e.g. Judge et al., 1988, for details). These are:

Uncensored Mean (mean of the latent variable):

$$
E\left(y_{i}^{*}\right)=X_{i}^{\prime} \beta
$$

Truncated Mean (mean of positive observations):

$$
E\left(y_{i} / y_{i}>0\right)=X_{i}^{\prime} \beta+\sigma \frac{\varphi(.)}{\Phi(.)}
$$

Censored Mean (mean of all observations):

$$
E\left(y_{i}\right)=\Phi(.) E\left(y_{i} / y_{i}>0\right)
$$

where

$\Phi($.$) is the standard normal cumulative distribution function, and$ 
$\varphi($.$) is the standard normal probability distribution function, evaluated at \frac{X_{i}^{\prime} \beta}{\sigma}$

We are interested in how the average size of a temporary open market operation changes as various indicators of balance needs change. This way, we can evaluate the determinants of each type of operation and the sensitivity of the Desk to different variables in meeting reserve needs. In the context of the tobit model, we are interested in the marginal effects of $x_{i}$ on the expected value of the dependent variable, conditional on the fact that there is an operation. This expression can be derived from (6) as:

$$
\frac{\partial E\left(y_{i} / y_{i}>0\right)}{\partial x_{j}}=\beta_{j}\left[1-\left(\frac{X_{i}^{\prime} \beta}{\sigma}\right)\left[\frac{\varphi(.)}{\Phi(.)}\right]-\left[\frac{\varphi(.)}{\Phi(.)}\right]^{2}\right]
$$

The expression in (8) must be evaluated at a set of regressor values since the conditional mean regression function is not linear. A common choice of values is the sample means. Meanwhile, the ratio of the effects of any two explanatory variables on the conditional mean is simply the ratio of the coefficient estimates, independent of the regressor values, since the terms in squared brackets cancel each other:

$$
\frac{\frac{\partial E\left(y_{i} / y_{i}>0\right)}{\partial x_{j}}}{\frac{\partial E\left(y_{i} / y_{i}>0\right)}{\partial x_{k}}}=\frac{\beta_{j}}{\beta_{k}}
$$

\section{Empirical Analysis}

\subsection{Determinants of the Trading Desk's Reaction Function}

Before discussing the set of explanatory variables to include in the Desk's reaction function, we review the contents of a sample call sheet that is prepared by Board staff for the morning conference call, prior to the implementation of open market operations. A similar 
report is prepared by the Federal Reserve Bank of New York, and both reports are presented at the conference call. Table 3 shows this report. In order to provide a better illustration, we present data from February 12, 1997, which was a settlement Wednesday, on which an overnight $R P$ operation of $\$ 5.06$ billion was executed. The blank cells reflect revisions in the current format of the report since 1997. The missing information was not reported on daily call sheets at that time.

The upper left block of the table shows maintenance period averages. The second column displays data on required reserves for the current maintenance period, and projections for the two subsequent maintenance periods. In addition, there are assumptions about the demand for excess reserves and discount window borrowing for the current and future maintenance periods, as well as the average excess reserves and borrowed reserves achieved to date. Periodaverage supply and demand estimates are typically expressed in terms of excess reserve levels, i.e., relative to the period-average level of requirements, which, since the return to lagged reserve accounting in August 1998, is constant over a maintenance period. These numbers lead to a nonborrowed reserves $(N B R)$ demand assumption. The difference between this number and projected supply of $N B R$ gives the period average need for open market operations. On February 12,1997 , the reserve need for the maintenance period, as an average of the forecasts between New York and the Board, was approximately $\$ 440$ million $[=(1 / 2) \times(\$ 433$ million $+\$ 446$ million)]. Because it was the last day of the period, the "remaining need" to raise average $N B R$ to the assumed level was about $\$ 6.1$ billion ( $\$ 440$ million $\times 14$ ), which was close to the actual size of the operation implemented on that day. The difference between the estimated reserve need and the actual operation size may reflect various factors such as informal adjustments to reserve demand (based on interviews with bank reserve managers that morning) or the Desk's 
allowance for forecast errors based on recent trends. The last column in this section reports differences in the estimates for required reserves between the projection teams in New York and the Board. The value was nonzero because of contemporaneous reserves accounting at that time, where total required reserves were not known until the maintenance period was over. Since the return to lagged reserve accounting, reserve requirements for the current maintenance period are known with certainty and therefore this cell is always zero. ${ }^{\square}$

The upper right block in Table 3 displays daily data on free reserves $(F R)$-excess reserves less borrowed reserves, and total operating balances - the sum of total required balances and excess reserves. The data for the current date and future days reflect projections by the Board and New York teams. This table is useful for assessing daily balance needs, which display substantial differences from one day to another over the maintenance period.

The lower right block summarizes daily projections of the main autonomous factors that affect balance supplies. Autonomous factors are items on the Federal Reserve's balance sheet that are not directly controlled by the Federal Reserve, and projections of these factors underlie the forecasts of supply shown in the upper blocks. In order to maintain a level of reserves consistent with the target funds rate on each day, the Desk needs to forecast and offset the reserve effects of these autonomous factors. For instance, an increase in the Treasury's Federal Reserve balance or an increase in the public's demand for currency drain balances from the banking system. On the other hand, an increase in float (items in process of collection) adds to balance levels (see Meulendyke, 1998, Chapter 6). The "pool level" refers to the amount foreign

\footnotetext{
${ }^{7}$ Under the lagged reserve accounting regime, this cell is a "check point" to ensure that both teams are working with the same underlying reserves information when preparing their forecasts. If the number is different from zero, it indicates that there are some transfer problems of required reserves data between the two teams that need to be cleared before calculating the reserve needs.
} 
central banks have invested overnight in the Federal Reserve's investment facility. Transfer of funds into these accounts drain balances.

\section{Dependent Variable}

The variable that we seek to explain is the change in the maintenance period average level of reserves brought about by the Desk's temporary operations. Because long-term $R P$ operations are not intended to address immediate reserve needs, we only focus on overnight $R P \mathrm{~s}$, short-term $R P \mathrm{~s}$, overnight $M S P \mathrm{~s}$, and term $M S P \mathrm{~s}$. To calculate the effect of a temporary transaction on the period average level of reserves, we multiply the par value of the securities by the number of days spanned by the transaction, including weekends and holidays, and divide by fourteen (the number of days in the maintenance period) as in Feinman (1993) or Demiralp and Jorda (2002). For term $R P$ operations prior to October 1999, we incorporate the effects of early withdrawals that reduce the impact of term $R P \mathrm{~s}$.

\section{Independent Variables}

Our empirical strategy requires us to specify the determinants of the different types of open market operations the Desk chooses to execute on a given day. Based on the discussion of the sample call sheet, we choose the following list of explanatory variables.

\section{Days of the Maintenance Period}

The first element in deciding on the size of open market operations is the target level of reserves that the Desk aims to leave in the system on a given day. This target is likely to be different on different days of the maintenance period, reflecting the patterns in reserve demand

\footnotetext{
${ }^{8}$ Early withdrawals were allowed on most delivery-versus-payment type of repo transactions. On October 1, 1999 the Desk switched to triparty arrangements on a permanent basis in conducting open market operations. Early withdrawals ceased at that point because term triparty transactions unwind each day. This arrangement permits netting and facilitates the dealer's management of collateral.
} 
and the autonomous factors of reserve supply. In order to control for these patterns, we include dummy variables for certain days of the maintenance period.

Table 4 exhibits the relative frequencies of temporary operations on each day of the maintenance period, as well as daily excess reserves in the system for the two sub-samples determined in Section 3. While overnight $R P$ s are spread relatively evenly over the maintenance period, their relative frequency has increased drastically on each day in the post-1999 period. Within the latter sample, for instance, the Desk implemented an overnight $R P$ operation 85 percent of the time on a settlement Wednesday $(=78 / 92)$ versus 53 percent of the time $(=172 / 323)$ before 1999 .

Generally, rather than distributing their balance needs evenly over a maintenance period, banks exhibit a strong preference for concentrating their accumulation of Federal Reserve balances late in the maintenance period when the risk of being locked into unusable excess

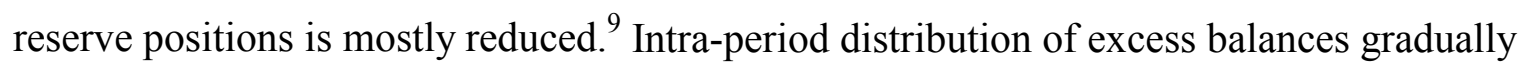
became more skewed in recent years, as shown in the lower panel of Table 4, because low total required balances increased the possibility of lock-ins. A natural outcome of the Desk's response to this demand pattern is the increased frequency of overnight $R P$ operations through the end of the maintenance period as observed in Table 4. This arrangement of reserve provision apparently satisfies banks' demands, as suggested by the smaller deviations of the funds rate from target, shown in Figure 3.

In general, the frequency of overnight $R P \mathrm{~s}$ on Fridays is lower than other days of the maintenance period. For reserve maintenance purposes, balances at the Federal Reserve on

\footnotetext{
${ }^{9}$ A depository institution is permitted to carry over a portion of current period excess reserves not greater than $\$ 50,000$ or four percent of its total requirement (less its clearing balance allowance) to the following maintenance period. Any excess above the permitted range is a "locked-in" balance that represents forgone investment opportunity.
} 
Friday have a three-day term rather than a one-day term. Because depository institutions want to avoid ending up with extra balances for three days, they are more eager to lend any excess funds in the market on Fridays (see Hamilton, 1997). Clouse and Dow (2002) further point out that banks are less willing to borrow on Fridays because reserves on Fridays are more expensive from their perspective. Specifically, a bank pays three days of interest in borrowing a dollar of reserves. However, if a bank has an overdraft on Friday, the overdraft charge is typically for only one day. ${ }_{10}$ Hence, reducing the risk of an overdraft on a Friday costs three times as much as reducing that risk on any other day. Together, these factors lead to a downward pressure on the funds rate on Fridays and consequently, all other things equal, the Desk tends not to inject money into the system on Fridays.

Term $R P$ operations display a somewhat different frequency distribution. While the overall likelihood of a term $R P$ operation has also increased in the post-1999 period, the probability of a term $R P$ operation is higher on the first Thursday and lower on the first Friday in both samples. The frequency also increases on the second Monday, addressing period-average reserve needs, but significantly declines on the settlement Wednesday, as the effects of term transactions would spill over into the next period.

The frequency of draining operations is significantly lower than $R P$ operations. Nonetheless, it is more likely to observe a $M S P$ operation on a Friday, when the reserve market is typically soft. Term $M S P$ operations are very seldom used; only 3 such operations have been implemented since 1999.

\footnotetext{
${ }^{10}$ The penalty for an overnight overdraft is set at four percentage points over the effective funds rate on the day of the overdraft.
} 


\section{Special Pressure Days}

Special pressure days are days on which payment flows are heavy and are characterized by higher uncertainty about end-of-day balances at the Federal Reserve. They include the day

after a holiday, quarter-end, year-end, first of the month, fifteenth of the month, and settlement of Treasury 2 and 5-year notes. Special pressure days have gained more attention in an environment of lower reserve requirements because payment-related demand, which often exceeds reserve-related demand on these days, is less interest elastic. Banks have no room to postpone payment needs, which elevate payment-related demands and put an upward pressure on the funds rate on special pressure days (see Whitesell, Demiralp, and Preslopsky, 2003). The Desk, therefore, has to be careful to provide a sufficient amount of reserves in the banking system on special pressure days.

\section{Projected Remaining Reserve Need}

This is the average of the New York and Board staffs' estimates of the nonborrowed reserve need adjusted for the remaining days in the maintenance period. The remaining reserve need is adjusted to reflect what is needed prior to each operation type, but after the execution of other operations, adjusted for relative entry times. Because of differences in entry times of different types of operations, the remaining reserve need is different for multiple operations executed on a single day.

Long-term $R P$ operations are not dependent upon the completion of the daily reserve supply forecast because they are intended to meet intermediate needs. Thus, they are conducted at 8:20 AM, when the general collateral $R P$ market is more liquid. Beginning in January 2002, the Desk began arranging 28-day $R P$ s only once a week, typically on a Thursday, instead of twice a week, which had been the regular practice since 2000 . 
In contrast to long-term $R P$ s, short-term and overnight $R P$ operations are conducted at 9:30 AM, after daily forecasts of supply of balances are available. Consequently, in calculating the remaining need prior to these operations, we adjust for the reserve impact of long-term $R P \mathrm{~s}$ conducted earlier in the day. When there is a need for two short-term operations of different maturities on the same day, the Desk conducts the two operations consecutively. On these occasions, prior to the announcement of the first operation, the Desk typically announces its intention to re-enter the market subsequent to the close of the first operation. There were 66 and 38 overlapping short-term $R P$ operations for the pre and post-1999 samples respectively, which constitute about $10 \%$ and $17 \%$ of total term $R P$ operations conducted in the two periods. Conversations with the Desk confirm that, when there are overnight and short-term $R P$ operations executed on the same day, the Desk first decides on the size of the term operation based on reserve needs that are expected to persist. After calculating the reserve impact of this operation on the remaining reserve need, they decide on the size of the overnight operation. This sequence of operations ensures that the Desk receives sufficient propositions to cover both operations. Accordingly, in calculating the remaining reserve need prior to a short-term $R P$ operation, we leave out the effects of same-day overnight $R P$ operations because these are executed after the term operation.

\section{Projected Daily Free Reserves Surplus or Deficiency}

In determining the size and the timing of its operations, the Desk not only considers the period-average reserve need but also the daily availability of balances at the Federal Reserve. The amount of daily $F R$ relative to the period average $F R$ allowance is used as an indicator of daily reserve demand. Similar to the adjustments for remaining reserve need, we modify the daily $F R$ surplus to reflect the effects of other operations decided on before the implementation 
of a particular operation. Following the declines in total required balances, the Desk has been paying particular attention to this variable to ensure that daily reserve needs are satisfied, as they became a more binding constraint from the depository institutions point of view.

\section{Deviation of the Morning Federal Funds Rate from the Target}

Each morning the Desk monitors the funds rate prior to the usual intervention time for short-term operations of 9:30 AM. Morning premiums typically provide an early sign of the demand pressures that will prevail later in the day and give the Desk a good indication of daily reserve demand.

\subsection{Estimation Results}

The sample period starts in January 1986. Consistent with the structural break test results, we split the sample period in 1999, when funds rate volatility became less pronounced. A simple way to explore the presence of a behavioral change in the Desk's reaction function, for each operation type $i$, consists of estimating the two sub-samples jointly with interactive dummy variables: ${ }^{2}$

$$
\begin{aligned}
y_{t}^{*}= & \alpha^{\text {pre99 }} \times\left(1-D_{99}\right)+\beta_{1}^{\text {pre99 }} \times\left(1-D_{99}\right) \times \text { First Thursday }+\beta_{2}^{\text {pre99 }} \times\left(1-D_{99}\right) \times \text { First Friday } \\
& +\beta_{3}^{\text {pre99 }} \times\left(1-D_{99}\right) \times \text { Second Friday }+\beta_{4}^{\text {pre99 }} \times\left(1-D_{99}\right) \times \text { Settlement Wednesday }+ \\
& \beta_{5}^{\text {pre99 }} \times\left(1-D_{99}\right) \times \text { Special Day }+\beta_{6}^{\text {pre99 }} \times\left(1-D_{99}\right) \times \text { Remaining Need }+ \\
& \beta_{7}^{\text {pre99 }} \times\left(1-D_{99}\right) \times \text { FR Surplus }+\beta_{8}^{\text {pre99 }} \times\left(1-D_{99}\right) \times\left(F F^{\text {Morning }}-F F^{\text {Target }}\right)
\end{aligned}
$$

\footnotetext{
${ }^{11}$ The first sample period has missing data from May 1993 through May 1994.

${ }^{12}$ In order to afford a reasonable number of degrees of freedom for this joint estimation, we did not include a dummy variable for each day of the maintenance period. Instead we only incorporated dummy variables for those days that could necessitate a different reserve target, based on our expectations of intra-period seasonality in the reserves market.
} 


$$
\begin{aligned}
& +\alpha^{\text {post } 99} \times\left(D_{99}\right)+\beta_{1}^{\text {post } 99} \times\left(D_{99}\right) \times \text { First Thursday }+\beta_{2}^{\text {post } 99} \times\left(D_{99}\right) \times \text { First Friday } \\
& +\beta_{3}^{\text {post } 99} \times\left(D_{99}\right) \times \text { Second Friday }+\beta_{4}^{\text {post } 99} \times\left(D_{99}\right) \times \text { Settlement Wednesday }+ \\
& \beta_{5}^{\text {post } 99} \times\left(D_{99}\right) \times \text { Special Day }+\beta_{6}^{\text {post } 99} \times\left(D_{99}\right) \times \text { Remaining Need }+\beta_{7}^{\text {post } 99} \times\left(D_{99}\right) \times F R \\
& \text { Surplus }+\beta_{8}^{\text {post } 99} \times\left(D_{99}\right) \times\left(F F^{\text {Morning }}-F F^{\text {Target }}\right)+\varepsilon_{t}
\end{aligned}
$$

where $D_{99}$ is a dummy variable that is equal to one for the period after July $13,1999$.

The tobit estimation results for the two sample periods are presented in Table 5.

Coefficient estimates for the two sub-samples are in the first and second columns, and the ratio of post-1999 to pre-1999 estimates is in the third column. From equation (9) this ratio can be interpreted as the relative size of marginal effects for the two sub-samples. In this setup, when there is a structural change in Desk behavior, we reject the null hypothesis that this ratio is equal to one. The results from this test are reported in the third column. The last two columns display the marginal effects of each variable as described in equation (8).

The top panel displays the regression results for overnight $R P$ operations. The coefficient on the first Thursday is positive and significant in the later sample, suggesting a greater chance of observing a larger overnight $R P$ on the first Thursday. This is consistent with a firmer demand on the first day of the period in the post-1999 sample. As shown in Table 4, excess reserve holdings on the first day have almost doubled in the later sample, likely due to a "carryover" effect of elevated demand on the previous settlement day. ${ }^{3}$ The average funds rate

\footnotetext{
${ }^{13}$ On the supply side, one other factor that has contributed to higher excess reserves on the first Thursday is the increase in the size of average as-of adjustments applied on the first day of the period. As-of adjustments are applied to a depository institution's position to offset the effect of certain types of errors on the institutions position. However, if the application of the as-of adjustment directly contributes to an excess or deficient position that exceeds the carryover limits, a Reserve Bank may permit the adjustment to be distributed over future periods. These
} 
deviation on the first Thursday has been only three basis points above the target in this period (not shown), suggesting that the Desk has been largely successful in eliminating demands on the first day. The last two columns in Table 5 display the marginal effect of each coefficient evaluated at the mean values when the dependent variable is positive. On the first Thursday, everything else remaining constant, the reserve impact of the average size of an $R P$ operation increases by about $\$ 97$ million in the second sample, or, equivalently, the average size of the $R P$ operation increases by about $\$ 1.4$ billion ( $\$ 97.03$ million $\times 14$ ).

On the first Friday, the reserve market is typically soft and the Desk addresses downward rate pressures by reducing the size of a potential $R P$ by about the same amount in both periods. The second Friday does not reveal any significant change in overnight $R P$ operations over the two periods either. Desk behavior on settlement Wednesday does not display a qualitative change over the two samples, although the average operation size is expected to be about seventy percent larger in the later period. In particular, settlement Wednesdays in the post-1999 sample boost the average size of an operation by about $\$ 3.6$ billion $(=\$ 262.44$ million $\times 14)$. The Desk increased its reliance on overnight $R P \mathrm{~s}$ on special pressure days in the later period, as expected. The average size of an $R P$ operation increases by about $\$ 2.3$ billion (= $\$ 164.03$ million $\times 14)$ on these days, compared with a $\$ 1.1$ billion increase in the earlier sample $(=\$ 76.14$ million $\times 14)$. Overall, the coefficient estimates for days of the maintenance period are consistent with our prior expectations regarding the reserve levels that the Desk aims to leave in the system on these days, after controlling for the variables that determine reserve pressures in the market.

The remaining three variables measure pressures in the market for balances. The Desk's response to "remaining reserve need" via overnight $R P$ operations declines somewhat in the

adjustments are applied on the first day of each of the subsequent maintenance periods. Because of the decline in total required balances, as-of adjustments are apportioned to future periods more frequently, since depository institutions have less flexibility to absorb these adjustments without running a reserve surplus or deficit. 
post-1999 period, but the marginal effects of the remaining reserve need are small in both periods. Meanwhile, the Desk is willing to cut back an overnight $R P$ by about $\$ 420$ million ( $\$ 30$ million $\times 14$ ) in both periods if the daily free reserve surplus estimate is revised up by $\$ 1.0$ billion. An increase in the morning rate prior to an operation reflects heightened market pressures and prompts the Desk to increase the size of an overnight operation in both periods. For example, one basis point deviation from the target raises the reserve impact of the average overnight $R P$ operation by about $\$ 3.2$ million (or the size of the operation by $\$ 3.2 \times 14=\$ 45$ million) in the later period. The ratio of the coefficients is not significantly different from one, but the slight decline in the later period may reflect the decay in the morning premium in recent years, as shown in Figure 3. This drop-off has come in response to the Desk's more ample provision of reserves on days when payment flows are expected to be elevated.

The second panel of Table 5 gives the estimation results for short-term $R P$ s. The relatively infrequent use of this operation leads to a significantly negative constant estimate for both samples, which is the base level of prediction when all of the other independent variables are zero. ${ }^{14}$ The signs of the coefficient estimates for the days of the maintenance period are consistent with our prior beliefs. The size of a term $R P$ operation was higher on the first Thursday in the pre-1999 period. Although the corresponding coefficient is not significant in the later period, the ratio of marginal effects does not reflect any significant structural change. The operation size is scaled back on both Fridays and the reduction in operation size is larger on the first Friday, similar to the downward adjustment of overnight $R P$ operations. Comparing the two

\footnotetext{
${ }^{14}$ We remove the observation on December 30, 1999 from our sample in estimating this equation. On this day, the Desk implemented two consecutive term $R P$ operations (a five-day operation for $\$ 7.15$ billion and a 14-day operation for $\$ 7.55$ billion) despite the fact that funds rate was trading extremely soft ( 175 basis points below the target). These operations were conducted in preparation for the century-date-change and do not reflect the typical use of term $R P$ operations.
} 
periods, the overall size of reduction on Fridays is somewhat lower in the post-1999 period, perhaps reflecting a smoother target for daily balances in the recent period, or less hesitance to engage in larger term operations when necessary. The Desk appears to have cut down the size of a term operation conducted on a settlement Wednesday in the pre-1999 period, but last day of the period is not treated differently in adjusting the size of term operations in the post-1999 period. Term $R P$ operations are not used to meet reserve demand on special pressure days either, as reserve pressures associated with these days are purely temporary and are not expected to persist. Although the coefficient in the pre-1999 period is negative, we fail to find a significant difference relative to the post-1999 coefficient.

The coefficients on the remaining reserve need are positive and significant in both samples, suggesting that the Desk's primary choice of addressing a sizable remaining need is term $R P$ operations. The marginal effects for the post-1999 period indicate that if the remaining reserve need is estimated to be $\$ 1.0$ billion higher on a particular day, the size of, say, a 2-day term operation is expected to be $\$ 60$ million $\times(14 / 2)=\$ 420$ million higher. The decline in this coefficient between the two samples may reflect increased sensitivity to updated information in the remaining days of the maintenance period. In the post-1999 period, the Desk is more likely to enter the market more frequently and address the remaining reserve need with an eye on likely data revisions in future days. The sensitivity of term operations to morning premiums in the funds rate is not significantly different from zero in the post-1999 sample, indicating that term operations are not used to protest daily deviations in interest rates but rather to address mediumterm reserve needs.

The next two panels present the results for draining operations. Draining operations are less frequently used than $R P$ operations, and they are particularly rare in the post-1999 sample. 
Despite the unavoidable risk of less precision due to a smaller sample size, the coefficient estimates for overnight MSP operations are mostly consistent with our prior beliefs. The average size of a draining operation increases on both Fridays, and this increase is more pronounced on the first Friday in the post-1999 period, consistent with downward adjustments in $R P$ operations on this day. Meanwhile, the average size of an overnight MSP operation decreases on settlement Wednesdays in both samples, reflecting prominent demand pressures. Not surprisingly, neither sample reflects any significant response on special pressure days. As shown in Table 4, while there were ten overnight draining operations that took place on special pressure days in the earlier period, there were no such operations in the post-1999 period.

The sensitivity of draining operations to a daily reserve surplus was significantly larger in the earlier sample, when operating balances were plentiful, than in the later sample, when having enough operating balances is a concern. Prior to the declines in reserve balances, the Desk was unconstrained by the level of total operating balances in the system, and it could respond to a daily free reserve surplus by draining the necessary amount of reserves to reach the periodaverage objective. Specifically, a $\$ 1.0$ billion revision in the daily free reserve surplus prompted the Desk to increase the size of an overnight $M S P$ by about $\$ 280$ million ( $\$ 20$ million $\times 14$ ) in this sample. In the later period, however, the Desk has to ensure that daily operating balances are sufficient for payment-related needs, even if period-average reserve estimates may suggest a surplus that needs to be drained. On those occasions when payment-related needs are dominant, morning premiums are generally firm prior to the Desk's usual intervention time, reflecting the depository institutions' demand for clearing needs despite higher than average excess reserves holdings. This consideration imposes a lower bound on draining operations and reduces the 
sensitivity of draining operations to a daily free reserve surplus in the post-1999 period, as shown by the statistically insignificant coefficient value.

The Desk's response to morning softness in the funds rate appears to be somewhat smaller in the later sample where one basis points deviation below the target increases the reserve impact of the average overnight $M S P$ operation by approximately $\$ 3.6$ million (or an increase in the size of the $M S P$ operation by $\$ 3.6$ million $\times 14=\$ 51.2$ million). Once again, we believe that the slight decline in the later period likely reflects the decline in the morning premium in the second sample, as discussed earlier.

Term MSP operations are the least frequently used operation type, and there were not enough degrees of freedom to estimate the post-1999 sample, as indicated by the fewer number of operations in Table 4. The estimation results for the earlier sample are presented in the last panel of Table 5. In contrast to overnight MSP operations that are more sizable on a Friday, term $M S P$ operations are likely to be smaller on a Friday, reflecting hesitance to engage in draining operations over a longer duration. The average size of a potential term MSP operation significantly declines on days when the morning funds rate is trading above the target. In particular, one basis point positive deviation from the target reduces the reserve impact of the average term $M S P$ operation by about $\$ 19$ million.

\section{Conclusion}

The decline in required balances in the 1990s triggered a debate over the role of reserve requirements. Critics of reserve requirements argued that lower reserve requirements would remove a distortionary tax on depository institutions, which would improve the world-wide competitive position of U.S. banks. Meanwhile, advocates argued that low reserve balances 
might complicate monetary policy operations, and increase short-term interest rate volatility. If that short-term rate volatility were transmitted to long-term rates, there could be negative effects on the real economy. Proponents of reserve requirements further argued that the role of the U.S. dollar as the primary world currency should also be considered. Without the cushion of reserves, the volatility in U.S. money markets would likely deter investors abroad from holding dollardenominated assets. In the event reductions in required balances did not bring about a permanent increase in the volatility of the federal funds rate. Volatility did increase initially but then fell back, remaining stable for a while before declining in recent years.

Sellon and Weiner $(1996,1997)$ noted that if the monetary authority is sufficiently flexible in modifying existing mechanisms for providing liquidity to the banking system, a decline in reserve requirements does not necessarily imply an increase in the volatility of shortterm interest rates, as long as there is a demand for central bank balances. In this paper, we investigated the Trading Desk's reaction function to test the hypothesis that changes in the procedures for supplying liquidity are one reason why funds rate volatility has remained low even as required balances have declined. Our analysis confirms that interest rate volatility depends essentially on institutional arrangements for providing and absorbing liquidity, rather than the level of reserve requirements.

The daily conduct of open market operations is influenced by a wide variety of factors. From this set, we chose several that seem important in determining the size of temporary operations. They include particular days of the maintenance period to measure recurring "seasonal" effects and indicators of pressure arising from reserve demand. Our model provided a framework for showing how the Desk's response to these variables has changed. Our findings 
indicate that the Desk has tailored its operations to address the new demand pattern that is associated with lower reserve requirements.

The decline in funds rate volatility over the last two years was reinforced by policy easing that generated an upturn in requirement-related demand for balances. Future policy tightening could push the demand for balances related to reserve requirements below paymentrelated demand. Under this scenario, required clearing balances might not rise enough to bring total required balances above payment-related needs because depository institutions reach a limit in their ability to use earnings credits that can be exchanged for Federal Reserve services. Consequently, more banks may need to hold excess reserve balances to meet their paymentrelated demand, which makes it more difficult from the Desk's perspective to predict the balance needs on a daily basis.

Faced with the potential for higher interest rate volatility, the Federal Reserve System took several steps to contain it. First, the Federal Reserve continued to support the payment of interest on reserves as a way to offset the cost of holding idle reserve balances and reduce the incentive to avoid reserve requirements. Second, in January 2003, the Board of Governors replaced the current discount window with a Lombard facility, moving it closer to an "operating band" for interest rates, similar to the practice in those countries that conduct monetary policy without relying on reserve requirements. Under the new system, the primary credit facility allows sound financial institutions the opportunity to borrow short-term funds at an initial rate of 100 basis points above the FOMC's target fed funds rate. The secondary credit facility is available to institutions that do not qualify for primary credit. Assuming an increased willingness of institutions to borrow due to the reduction in the administrative burden, the 
primary credit facility may reduce the volatility in the funds rate by serving as an upper bound in the federal funds market.

The evidence presented in this paper shows that, so far the Federal Reserve has been successful in adapting to a world of low and declining reserve balances and limiting the volatility of the funds rate. An important reason for that success has been the closer attention paid by the Desk to the daily pattern of demand balances over the maintenance period. Based on these results, we believe that the current mechanism for implementing monetary policy does not face any significant threat in the near future. 


\section{Table 1}

\section{Structural Break Tests}

\begin{tabular}{|c|c|c|}
\hline Measure of Volatility & SupF(1|0) & Date of Break \\
\hline $\begin{array}{c}\text { High-Low Range } \\
\text { (January 2, 1986- February 5, 2003) }\end{array}$ & $135.52 * *$ & July $13,1999 * * *$ \\
\hline $\begin{array}{c}\text { High-Low Range } \\
\text { (January 3, 1994- February 5, 2003) }\end{array}$ & $107.54 * *$ & January 12,2000 \\
\hline $\begin{array}{c}\text { Intraday Volatility } \\
\text { (January 3, 1994- February 5, 2003) }\end{array}$ & $120.21 * *$ & January 11,2000 \\
\hline \multicolumn{3}{|c|}{$\begin{array}{l}* * \text { and } * \text { indicate significance at } 99 \% \text { and } 95 \% \text { level of confidence respectively. } \\
* * * \text { Structural Break tests using the maximum number of available observations for the high-low range (sample } \\
\text { period starting at January } 3,1985 \text { ) suggest the same break point. }\end{array}$} \\
\hline \multicolumn{3}{|c|}{$\begin{array}{l}\text { Application of Information Criteria for the Break Dates Detected with Bai and Perron } \\
\text { (1998) Tests }\end{array}$} \\
\hline Measure of Volatility & $\begin{array}{l}\text { Number of breaks } \\
\text { chosen by } L W Z\end{array}$ & $\begin{array}{l}\text { Number of breaks } \\
\text { chosen by BIC }\end{array}$ \\
\hline $\begin{array}{c}\text { High-Low Range } \\
\text { (January 2, 1986- February 5, 2003) }\end{array}$ & 0 & 1 \\
\hline $\begin{array}{c}\text { High-Low Range } \\
\text { (January 3, 1994- February 5, 2003) }\end{array}$ & 1 & 1 \\
\hline $\begin{array}{c}\text { Intraday Volatility } \\
\text { (January 3, 1994- February 5, 2003) }\end{array}$ & 1 & 1 \\
\hline
\end{tabular}


Table 2

\begin{tabular}{|c|c|c|c|c|c|c|c|}
\hline \multirow[b]{2}{*}{ Year } & \multicolumn{2}{|c|}{$\begin{array}{c}\text { Overnight } \\
\text { Repurchase } \\
\text { Agreements }\end{array}$} & \multicolumn{2}{|c|}{$\begin{array}{c}\text { Term Repurchase } \\
\text { Agreements }\end{array}$} & \multicolumn{2}{|c|}{$\begin{array}{c}\text { Matched Sale-Purchase } \\
\text { Transactions }\end{array}$} & \multirow{2}{*}{\begin{tabular}{|c|}
$\begin{array}{c}\text { Memo: } \\
\text { Total } \\
\text { Operating } \\
\text { Balances }\end{array}$ \\
\\
Year-end \\
level \\
( \$ billions)
\end{tabular}} \\
\hline & $\begin{array}{c}\text { Number of } \\
\text { market } \\
\text { entries }\end{array}$ & $\begin{array}{l}\text { Volume } \\
\text { (\$ billions) }\end{array}$ & $\begin{array}{c}\text { Number of } \\
\text { market } \\
\text { entries }\end{array}$ & $\begin{array}{c}\text { Volume } \\
\text { (\$ billions) }\end{array}$ & $\begin{array}{c}\text { Number of } \\
\text { market } \\
\text { entries }\end{array}$ & $\begin{array}{c}\text { Volume } \\
\text { (\$ billions) }\end{array}$ & \\
\hline 1986 & 113 & 267 & 24 & 95 & 9 & 21 & 48.1 \\
\hline 1987 & 112 & 292 & 46 & 258 & 6 & 19 & 41.8 \\
\hline 1988 & 106 & 245 & 30 & 108 & 22 & 63 & 39.3 \\
\hline 1989 & 71 & 160 & 18 & 117 & 15 & 19 & 38.3 \\
\hline 1990 & 93 & 253 & 34 & 136 & 19 & 48 & 38.4 \\
\hline 1991 & 108 & 320 & 34 & 188 & 31 & 75 & 29.4 \\
\hline 1992 & 89 & 255 & 55 & 279 & 20 & 29 & 31.8 \\
\hline 1993 & 83 & 267 & 80 & 361 & 5 & 11 & 34.9 \\
\hline 1994 & 80 & 218 & 66 & 257 & 5 & 13 & 30.5 \\
\hline 1995 & 68 & 206 & 60 & 249 & 16 & 49 & 29.6 \\
\hline 1996 & 94 & 350 & 65 & 248 & 20 & 53 & 24.5 \\
\hline 1997 & 140 & 577 & 75 & 394 & 0 & 0 & 30.8 \\
\hline 1998 & 143 & 543 & 64 & 254 & 22 & 68 & 26.3 \\
\hline 1999 & 146 & 521 & 92 & 426 & 13 & 22 & 24.0 \\
\hline 2000 & 139 & 547 & 87 & 343 & 16 & 42 & 19.0 \\
\hline 2001 & 131 & 857 & 134 & 641 & 10 & 25 & 17.5 \\
\hline 2002 & 136 & 604 & 101 & 539 & 7 & 11 & 22.5 \\
\hline
\end{tabular}


Table 3

Key Reserve Data And Projections

12-Feb-1997

(in millions)

\begin{tabular}{|c|c|c|c|c|c|c|c|c|c|}
\hline \multicolumn{10}{|c|}{ Reserve Assumptions and Projections } \\
\hline \multirow{2}{*}{$\begin{array}{l}\text { Reserve } \\
\text { Period } \\
\text { Ending }\end{array}$} & \multicolumn{4}{|c|}{ Assumptions } & \multirow{2}{*}{$\begin{array}{c}\text { Non- } \\
\text { Borrowed } \\
\text { Reserve } \\
\text { Assumption }\end{array}$} & \multirow{2}{*}{\multicolumn{2}{|c|}{$\begin{array}{c}\text { Projected } \\
\text { Supply of } \\
\text { Non- } \\
\text { Borrowed }\end{array}$}} & \multirow{2}{*}{$\begin{array}{c}\text { Open* } \\
\text { Market } \\
\text { Operations }\end{array}$} & \multirow{2}{*}{$\begin{array}{l}\text { Diff. In } \\
\text { Req. } \\
\text { Reserve } \\
\text { Estimates } \\
\text { (NY-BD) }\end{array}$} \\
\hline & Required & & Excess & Borrowing & & & & & \\
\hline \multirow{2}{*}{ 12-Feb } & \multirow{2}{*}{47,920} & Assump.: & 1000 & 75 & \multirow{2}{*}{48,845} & NY: & 48,412 & 433 & \multirow{2}{*}{-101} \\
\hline & & To Date: & 623 & 24 & & BD: & 48,399 & 446 & \\
\hline 26-Feb & 47,031 & \multicolumn{2}{|r|}{1000} & 75 & 47,956 & $\begin{array}{l}\text { NY: } \\
\text { BD: }\end{array}$ & $\begin{array}{l}39,124 \\
39,002 \\
\end{array}$ & $\begin{array}{l}8,832 \\
8,954 \\
\end{array}$ & -292 \\
\hline 12-Mar & 47,153 & \multicolumn{2}{|r|}{1000} & 75 & 48,078 & $\begin{array}{l}\text { NY: } \\
\text { BD: }\end{array}$ & $\begin{array}{l}36,316 \\
37,093\end{array}$ & $\begin{array}{l}11,762 \\
10,985\end{array}$ & 646 \\
\hline
\end{tabular}

\begin{tabular}{|c|c|c|c|c|c|}
\hline \multicolumn{6}{|c|}{ Free Reserves and Total Operating Balances } \\
\hline \multirow[b]{2}{*}{ Date } & \multicolumn{3}{|c|}{ Free Reserves } & \multicolumn{2}{|c|}{ Op. Bals.** } \\
\hline & Day & Board & NY & Board & NY \\
\hline 30-Jan-97 & Th & 311 & & 17,840 & \\
\hline 31-Jan-97 & $\mathrm{F}$ & 2,500 & & 20,309 & \\
\hline 3-Feb-97 & M & -178 & & 17,471 & \\
\hline 4-Feb-97 & $\mathrm{T}$ & -269 & & 17,525 & \\
\hline 5-Feb-97 & W & $-1,488$ & & 16,240 & \\
\hline 6-Feb-97 & Th & 931 & & 18,721 & \\
\hline 7-Feb-97 & $\mathrm{F}$ & 629 & & 18,449 & \\
\hline 10-Feb-97 & M & -81 & & 18,257 & \\
\hline 11-Feb-97 & $\mathrm{T}$ & -963 & & 16,721 & \\
\hline 12-Feb-97 & W & -938 & -664 & 17,305 & 17,746 \\
\hline 13-Feb-97 & Th & & & & \\
\hline 14-Feb-97 & $\mathrm{F}$ & & & & \\
\hline 17-Feb-97 & $M$ & & & & \\
\hline 18-Feb-97 & $\mathrm{T}$ & & & & \\
\hline 19-Feb -97 & W & & & & \\
\hline
\end{tabular}

${ }^{*} \mathrm{OMO}$ includes anticipated redemptions and assumes that outstanding RPs mature without replacement.

${ }^{* *}$ Operating balances are a balance sheet measure that do not include as-of adjustments, include required clearing balances, and raise overdrafts to zero. Future operating balances include the borrowing assumption along with other staff projections.

\begin{tabular}{|c|c|cc|c|c|c|c|}
\hline \hline \multicolumn{7}{|c|}{ Historical Reserve Data } \\
\hline \hline $\begin{array}{c}\text { Period } \\
\text { Ending }\end{array}$ & $\begin{array}{c}\text { Non- } \\
\text { Borrow } \\
\text { ed }\end{array}$ & $\begin{array}{c}\text { Total } \\
\text { Borrowing } \\
\text { Prim. Scnd. }\end{array}$ & Seas. & $\begin{array}{c}\text { Total } \\
\text { Reserves }\end{array}$ & $\begin{array}{c}\text { Excess } \\
\text { Reserves }\end{array}$ & $\begin{array}{l}\text { Required } \\
\text { Reserves }\end{array}$ & Operating \\
\hline 18-Dec & 50,638 & 112 & 67 & 50,750 & 1,411 & 49,338 & 20,197 \\
01-Jan & 51,990 & 143 & 64 & 52,132 & 1,537 & 50,595 & 21,179 \\
15-Jan & 52,048 & 53 & 18 & 52,100 & 1,240 & 50,860 & 20,611 \\
29-Jan & 49,331 & 32 & 18 & 49,363 & 1,206 & 48,157 & 17,755 \\
\hline
\end{tabular}

\begin{tabular}{|l|cc|c|}
\hline \hline \multicolumn{3}{|c|}{ Today's Key Factors Projections } \\
\hline & Board & NY & $\begin{array}{r}\text { Res. } \\
\text { Diff. }\end{array}$ \\
\hline $\begin{array}{l}\text { Treas. Bal. } \\
\text { CIC Change }\end{array}$ & 5,104 & 5,055 & 49 \\
Float Level & & & \\
Pool Level & \multicolumn{2}{|c|}{12,700} & -- \\
\hline Total Diff. & & \\
\hline
\end{tabular}

${ }^{* * *}$ Primary and secondary borrowing was initiated during the maintenance period ending 1/22/03. 
Table 4

Temporary Open Market Operations over the Maintenance Period

\begin{tabular}{|c|c|c|c|c|c|c|c|c|c|c|c|}
\hline & THU & FRI & MON & TUE & WED & THU & FRI & MON & TUE & WED & $\begin{array}{c}\text { Special } \\
\text { Pressure Days }\end{array}$ \\
\hline \multicolumn{12}{|c|}{ Overnight RP } \\
\hline Pre-1999 & 65 & 48 & 43 & 52 & 50 & 49 & 48 & 48 & 60 & 172 & 182 \\
\hline Post-1999 & 74 & 39 & 46 & 48 & 44 & 53 & 33 & 41 & 33 & 78 & 115 \\
\hline \multicolumn{12}{|c|}{ Short-term RP } \\
\hline Pre-1999 & 103 & 15 & 83 & 41 & 33 & 94 & 19 & 115 & 66 & 6 & 102 \\
\hline Post-1999 & 27 & 17 & 22 & 15 & 17 & 29 & 29 & 35 & 25 & 10 & 40 \\
\hline \multicolumn{12}{|l|}{$M S P$} \\
\hline Pre-1999 & 6 & 27 & 5 & 8 & 17 & 25 & 31 & 11 & 14 & 22 & 10 \\
\hline Post-1999 & 2 & 10 & 0 & 7 & 6 & 4 & 4 & 0 & 2 & 1 & 0 \\
\hline \multicolumn{12}{|l|}{ Term MSP } \\
\hline Pre-1999 & 15 & 7 & 11 & 14 & 8 & 14 & 3 & 12 & 8 & 0 & 13 \\
\hline Post-1999 & 0 & 0 & 0 & 0 & 0 & 1 & 1 & 0 & 1 & 0 & 0 \\
\hline \multicolumn{12}{|c|}{ Total Number of Occurrences within the Sample } \\
\hline Pre-1999 & 316 & 309 & 279 & 318 & 319 & 314 & 317 & 292 & 322 & 323 & 511 \\
\hline Post-1999 & 91 & 92 & 87 & 90 & 90 & 87 & 91 & 76 & 92 & 92 & 151 \\
\hline
\end{tabular}

\section{Memo:}

Excess Reserves over the Maintenance Period (\$ millions)

\begin{tabular}{l|cccccccccc|c} 
& & & & & & & & & & Special \\
& THU & FRI & MON & TUE & WED & THU & FRI & MON & TUE & WED & Pressure Days \\
\hline Pre-1999 & 1,357 & 797 & 1,022 & 897 & 824 & 792 & 1,367 & 2,156 & 2,157 & 4,668 & 2,300 \\
Post-1999 & 2,130 & -99 & 810 & 466 & 1,300 & 1,646 & 1,651 & 3,035 & 3,496 & 7,030 & 4,488 \\
\hline \hline
\end{tabular}

Pre-1994 period is January 2, 1986 through July 12, 1999. Post-1999 period is July 13, 1999 through February 5, 2003.

*Special pressure days: Day after a holiday, quarter-end, year-end, first of the month, fifteenth of the month, and settlement of Treasury 2 and 5 -year notes. 
Table 5: Tobit Regressions for Temporary Open Market Operations

Dependent Variable: Overnight $R P$ (\$ millions)

\begin{tabular}{|c|c|c|c|c|c|}
\hline & (1) & $(2)$ & Ratio & \multicolumn{2}{|c|}{ Marginal Effect } \\
\hline Explanatory Variables & 1986-1999 & 1999-2003 & $(2) /(1)$ & 1986-1999 & $1999-2003$ \\
\hline Constant & $\begin{array}{c}-633.60 \\
(-28.33)^{* *}\end{array}$ & $\begin{array}{c}-362.53 \\
(-11.80)^{* *}\end{array}$ & $0.57 * *$ & -275.71 & -157.75 \\
\hline First Thursday & $\begin{array}{l}42.93 \\
(1.34)\end{array}$ & $\begin{array}{c}222.99 \\
(5.29)^{* *}\end{array}$ & $5.19 * *$ & 18.68 & 97.03 \\
\hline First Friday & $\begin{array}{c}-125.66 \\
(-3.19)^{* *}\end{array}$ & $\begin{array}{l}-160.23 \\
(-2.34)^{*}\end{array}$ & 1.28 & -54.68 & -69.72 \\
\hline Second Friday & $\begin{array}{l}-32.44 \\
(-0.92)\end{array}$ & $\begin{array}{l}13.34 \\
(0.26)\end{array}$ & -0.41 & -14.11 & 5.80 \\
\hline Settlement Wednesday & $\begin{array}{c}354.89 \\
(13.08)^{* *}\end{array}$ & $\begin{array}{c}603.10 \\
(13.13)^{* *}\end{array}$ & $1.70 * *$ & 154.43 & 262.44 \\
\hline Special Pressure Days & $\begin{array}{c}174.99 \\
(7.36)^{* *}\end{array}$ & $\begin{array}{c}376.95 \\
(9.87)^{* *}\end{array}$ & $2.15 * *$ & 76.14 & 164.03 \\
\hline Remaining Reserve Need & $\begin{array}{c}0.04 \\
(15.68)^{* *}\end{array}$ & $\begin{array}{c}0.02 \\
(4.91)^{* *}\end{array}$ & $0.41 * *$ & 0.02 & 0.01 \\
\hline Daily Free Reserves Surplus & $\begin{array}{c}-0.07 \\
(-16.94) * *\end{array}$ & $\begin{array}{c}-0.07 \\
(-15.22)^{* *}\end{array}$ & 1.10 & -0.03 & -0.03 \\
\hline Morning Deviation (basis points) & $\begin{array}{c}8.57 \\
(19.69)^{* *} \\
\end{array}$ & $\begin{array}{c}7.32 \\
(5.89)^{* *}\end{array}$ & 0.85 & 3.73 & 3.19 \\
\hline Log-likelihood & $-9,02$ & 0.85 & Scaling I & & 0.44 \\
\hline
\end{tabular}

Dependent Variable: Short-term $R P(\$$ millions)

\begin{tabular}{|c|c|c|c|c|c|}
\hline \multirow[b]{2}{*}{ Explanatory Variables } & \multirow{2}{*}{$\begin{array}{c}(1) \\
1986-1999\end{array}$} & \multirow{2}{*}{$\begin{array}{c}(2) \\
1999-2003\end{array}$} & \multirow{2}{*}{$\begin{array}{c}\text { Ratio } \\
(2) /(1)\end{array}$} & \multicolumn{2}{|c|}{ Marginal Effect } \\
\hline & & & & 1986-1999 & 1999-2003 \\
\hline Constant & $\begin{array}{c}-2,931.27 \\
(-25.30)^{* *}\end{array}$ & $\begin{array}{c}-2,587.15 \\
(-13.94)^{* *}\end{array}$ & 0.88 & $-1,275.53$ & $-1,125.78$ \\
\hline First Thursday & $\begin{array}{c}532.80 \\
(3.98)^{* *}\end{array}$ & $\begin{array}{c}306.41 \\
(1.33)\end{array}$ & 0.58 & 231.84 & 133.33 \\
\hline First Friday & $\begin{array}{l}-4,005.56 \\
(-11.68)^{* *}\end{array}$ & $\begin{array}{l}-2,611.91 \\
(-6.86)^{* *}\end{array}$ & $0.65^{* *}$ & $-1,743.00$ & $-1,136.56$ \\
\hline Second Friday & $\begin{array}{c}-2,904.94 \\
(-10.35)^{* *}\end{array}$ & $\begin{array}{l}-1,301.10 \\
(-4.21)^{* *}\end{array}$ & $0.45^{* *}$ & $-1,264.07$ & -566.17 \\
\hline Settlement Wednesday & $\begin{array}{l}-3,030.09 \\
(-9.00)^{* *}\end{array}$ & $\begin{array}{c}-258.58 \\
(-0.79)\end{array}$ & $0.09 * *$ & $-1,318.53$ & -112.52 \\
\hline Special Pressure Days & $\begin{array}{l}-267.86 \\
(-1.99)^{*}\end{array}$ & $\begin{array}{l}103.84 \\
(0.50)\end{array}$ & -0.39 & -116.56 & 45.18 \\
\hline Remaining Reserve Need & $\begin{array}{c}0.24 \\
(15.83)^{* *}\end{array}$ & $\begin{array}{c}0.14 \\
(8.72)^{* *}\end{array}$ & $0.57 * *$ & 0.10 & 0.06 \\
\hline Daily Free Reserves Surplus & $\begin{array}{c}-0.31 \\
(-16.28)^{* *}\end{array}$ & $\begin{array}{c}-0.20 \\
(-7.03)^{* *}\end{array}$ & $0.64 * *$ & -0.13 & -0.09 \\
\hline Morning Deviation (basis points) & $\begin{array}{c}11.04 \\
(4.14)^{* *} \\
\end{array}$ & $\begin{array}{c}8.23 \\
(1.27) \\
\end{array}$ & 0.75 & 4.80 & 3.58 \\
\hline Log-likelihood & $-7,8$ & 4.77 & Scaling & tor $^{* * * *}$ & 0.35 \\
\hline
\end{tabular}


Dependent Variable: Overnight $M S P(\$$ millions $)$

\begin{tabular}{|c|c|c|c|c|c|}
\hline \multirow[b]{2}{*}{ Explanatory Variables } & $(1)$ & $(2)$ & Ratio & \multicolumn{2}{|c|}{ Marginal Effect } \\
\hline & 1986-1999 & 1999-2003 & $(2) /(1)$ & 1986-1999 & 1999-2003 \\
\hline Constant & $\begin{array}{c}-643.38 \\
(-13.67)^{* *}\end{array}$ & $\begin{array}{l}-528.61 \\
(-8.58)^{* *}\end{array}$ & $0.82 *$ & -279.97 & -230.02 \\
\hline First Thursday & $\begin{array}{l}-79.89 \\
(-1.05)\end{array}$ & $\begin{array}{c}-161.06 \\
(-1.17)\end{array}$ & 2.02 & -34.76 & -70.08 \\
\hline First Friday & $\begin{array}{c}267.61 \\
(5.36)^{* *}\end{array}$ & $\begin{array}{c}500.72 \\
(4.37)^{* *}\end{array}$ & 1.87 & 116.45 & 217.89 \\
\hline Second Friday & $\begin{array}{c}265.74 \\
(5.69)^{* *}\end{array}$ & $\begin{array}{l}183.54 \\
(1.82)\end{array}$ & 0.69 & 115.64 & 79.87 \\
\hline Settlement Wednesday & $\begin{array}{l}-146.47 \\
(-2.43)^{*}\end{array}$ & $\begin{array}{l}-423.96 \\
(-2.39)^{*}\end{array}$ & 2.89 & -63.74 & -184.49 \\
\hline Special Pressure Days & $\begin{array}{c}-123.37 \\
(-1.95)\end{array}$ & $\begin{array}{c}-1,579.08 \\
(-0.14)\end{array}$ & 12.80 & -53.68 & -687.13 \\
\hline Remaining Reserve Need & $\begin{array}{c}-0.04 \\
(-9.24)^{* *}\end{array}$ & $\begin{array}{c}-0.02 \\
(-3.07)^{*}\end{array}$ & $0.49 * *$ & -0.02 & -0.01 \\
\hline Daily Free Reserves Surplus & $\begin{array}{c}0.05 \\
(6.75)^{* *}\end{array}$ & $\begin{array}{c}0.01 \\
(0.85)\end{array}$ & $0.20 * *$ & 0.02 & 0.00 \\
\hline Morning Deviation (basis points) & $\begin{array}{c}-17.85 \\
(-11.97)^{* *}\end{array}$ & $\begin{array}{c}-8.40 \\
(-3.73)^{* *}\end{array}$ & $0.47 * *$ & -7.77 & -3.66 \\
\hline Log-likelihood & $-1,8$ & 0.00 & Scaling & tor $^{* * *}$ & 0.22 \\
\hline
\end{tabular}

The third column reports two-sided hypothesis tests results under the null hypothesis that ratio $=1$.

Dependent Variable: Term MSP (\$ millions)

\begin{tabular}{l|c|c}
\hline \hline Explanatory Variables & $1986-1999$ & Marginal Effect \\
\hline Constant & $-1,719.53$ & -748.25 \\
First Thursday & $(-10.02)^{* *}$ & \\
& 518.88 & 225.79 \\
First Friday & $(3.51)^{* *}$ & \\
& -594.67 & -258.77 \\
Second Friday & $(-2.56)^{*}$ & \\
& $-1,131.02$ & -492.16 \\
Settlement Wednesday & $(-3.42)^{* *}$ & \\
& $-6,280.66$ & $-2,733.00$ \\
Special Pressure Days & $(-0.85)$ & -101.74 \\
Remaining Reserve Need & -233.80 & -0.10 \\
Daily Free Reserves Surplus & $(-1.35)$ & 0.07 \\
Morning Deviation (basis points) & $(-9.46)^{* *}$ & \\
& 0.16 & -18.57 \\
\hline Log-likelihood & $(6.65)^{* *}$ & \\
\hline \hline
\end{tabular}

z-ratios are in parenthesis. $* *$ and $*$ indicate significance at $99 \%$ and $95 \%$ level of confidence respectively.

${ }^{* * *}$ Scaling factor (as described in equation (8)) is evaluated at sample averages on days when the dependent variable is positive. Pre-1994 period is January 2, 1986 through July 12, 1999. Post-1999 period is July 13, 1999 through February 5, 2003. 
Figure 1

Balances at Federal Reserve Banks, 1986-2002

(maintenance period average)

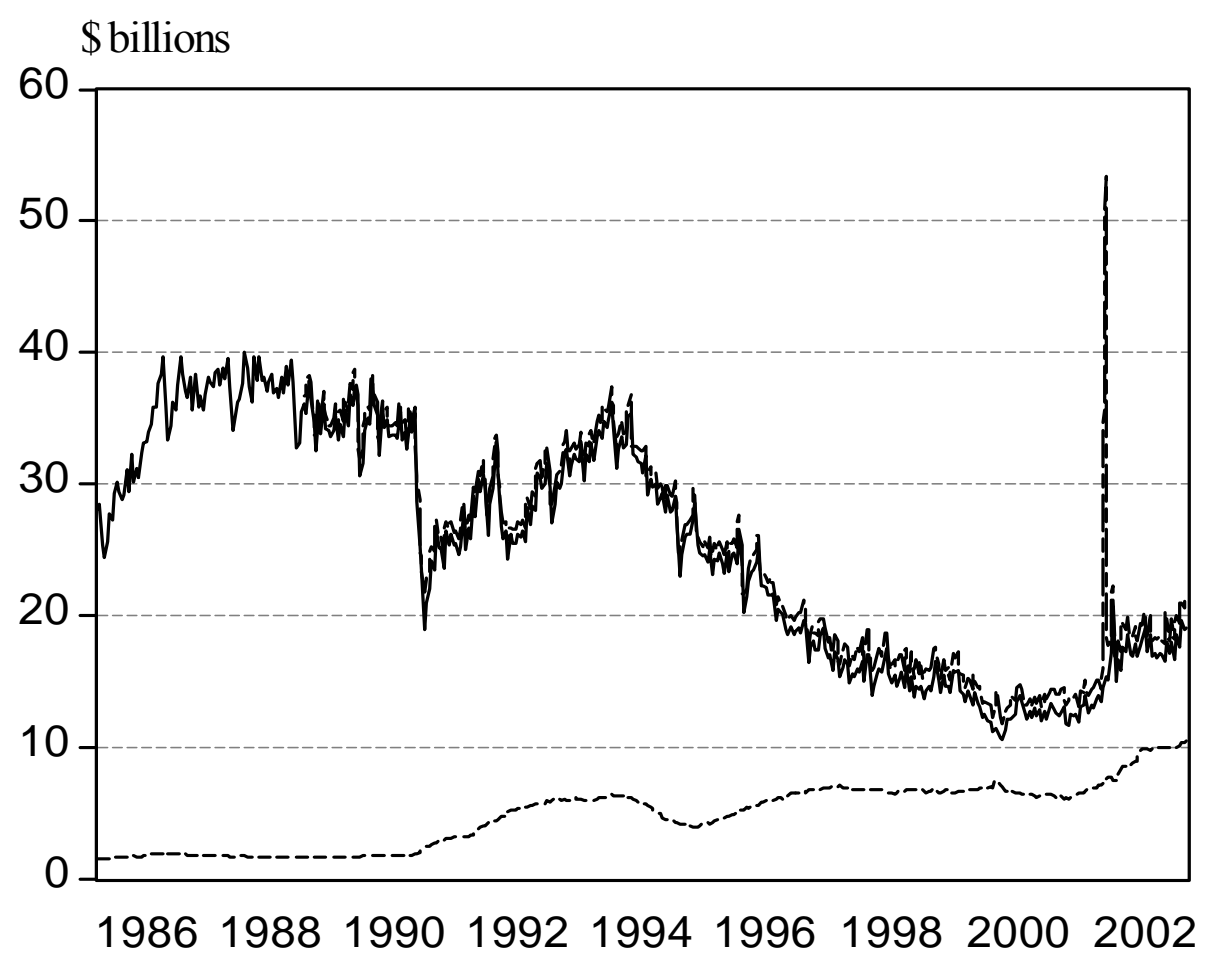

----- Required Clearing Balances

— Total Required Balances

--_ Total Operating Balances 
Figure 2

Mean Absolute Deviation of Daily Effective Funds Rate from Target

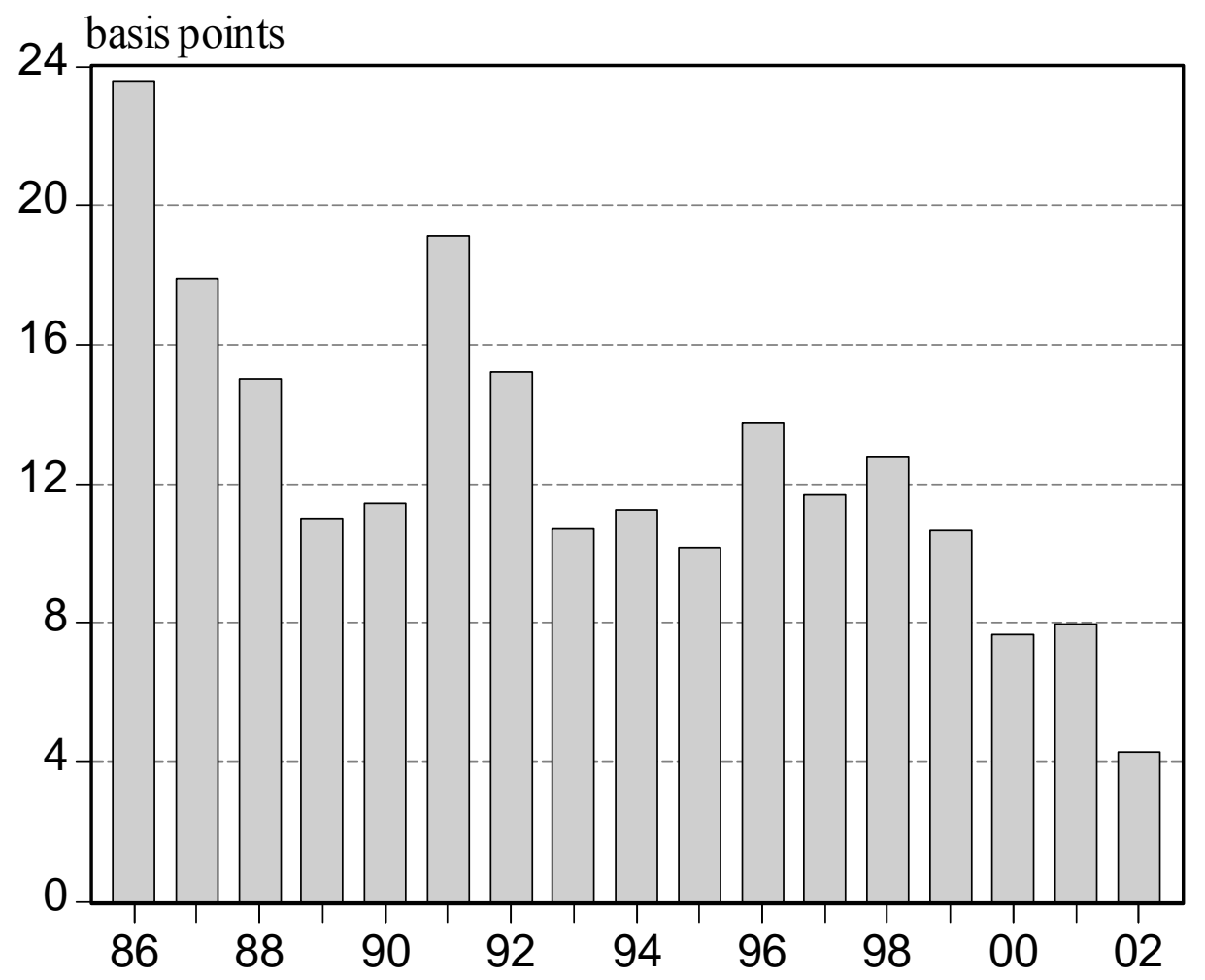


Figure 3

Average Deviation of Effective Funds Rate from Target

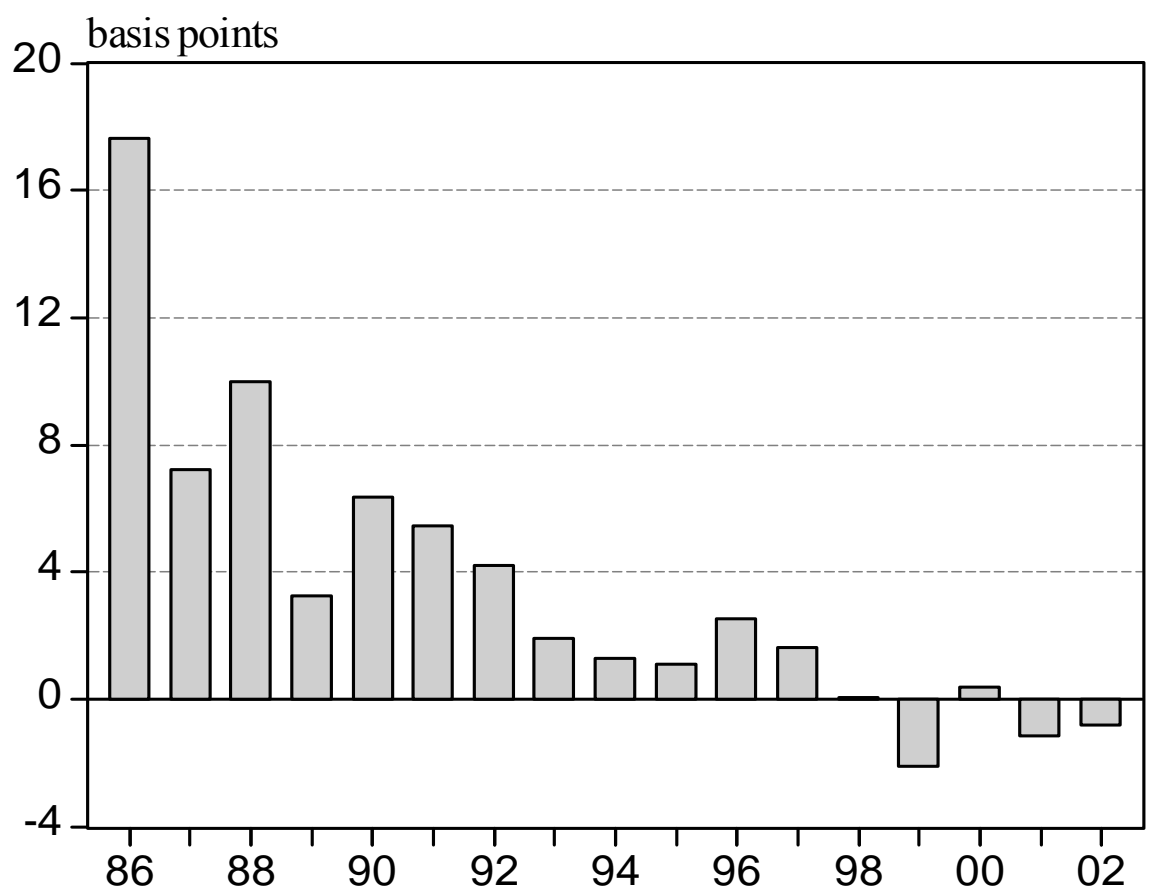

Average Deviation of Morning Funds Rate from Target*

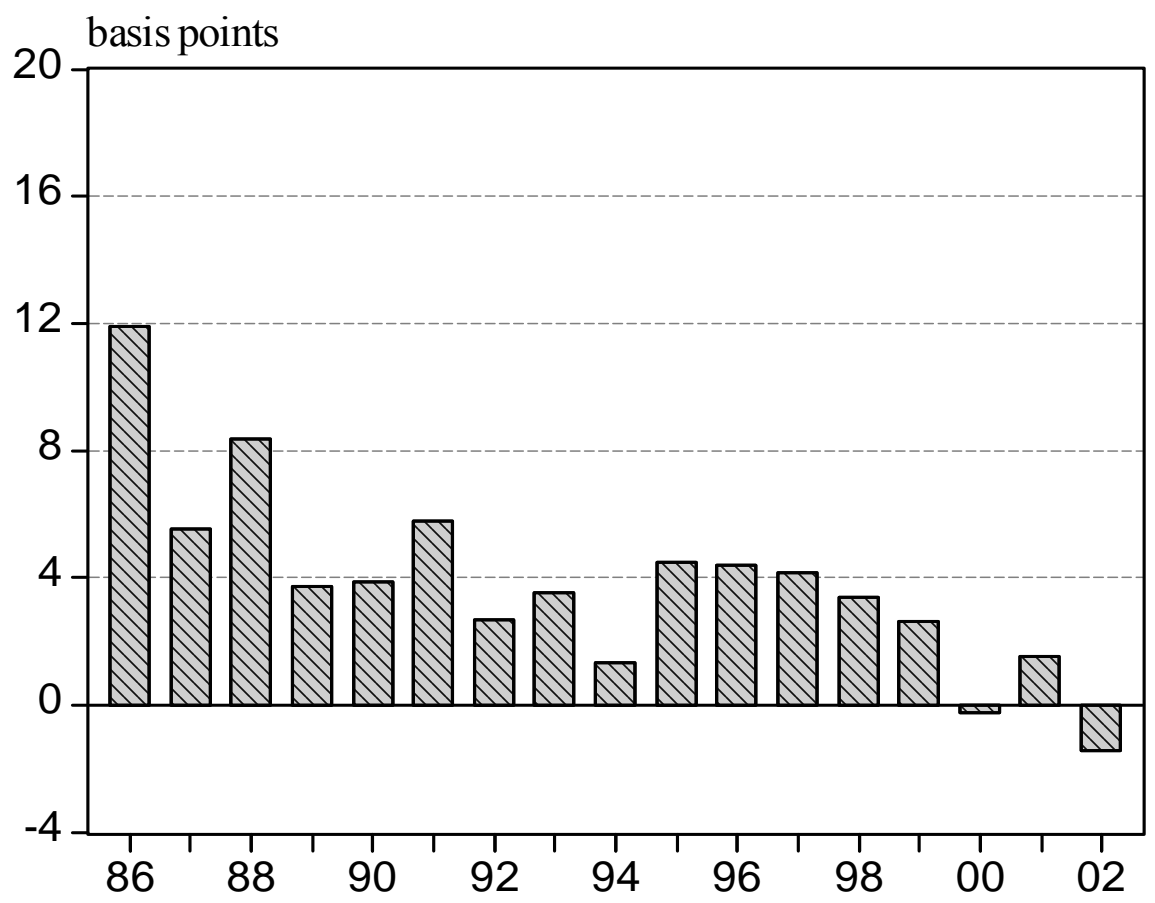

*Morning funds rate is the indicative rate prior to the usual time of Desk intervention at 9:30 AM. Range of trading values are averaged. 
Figure 4

Average Daily High-Low Range

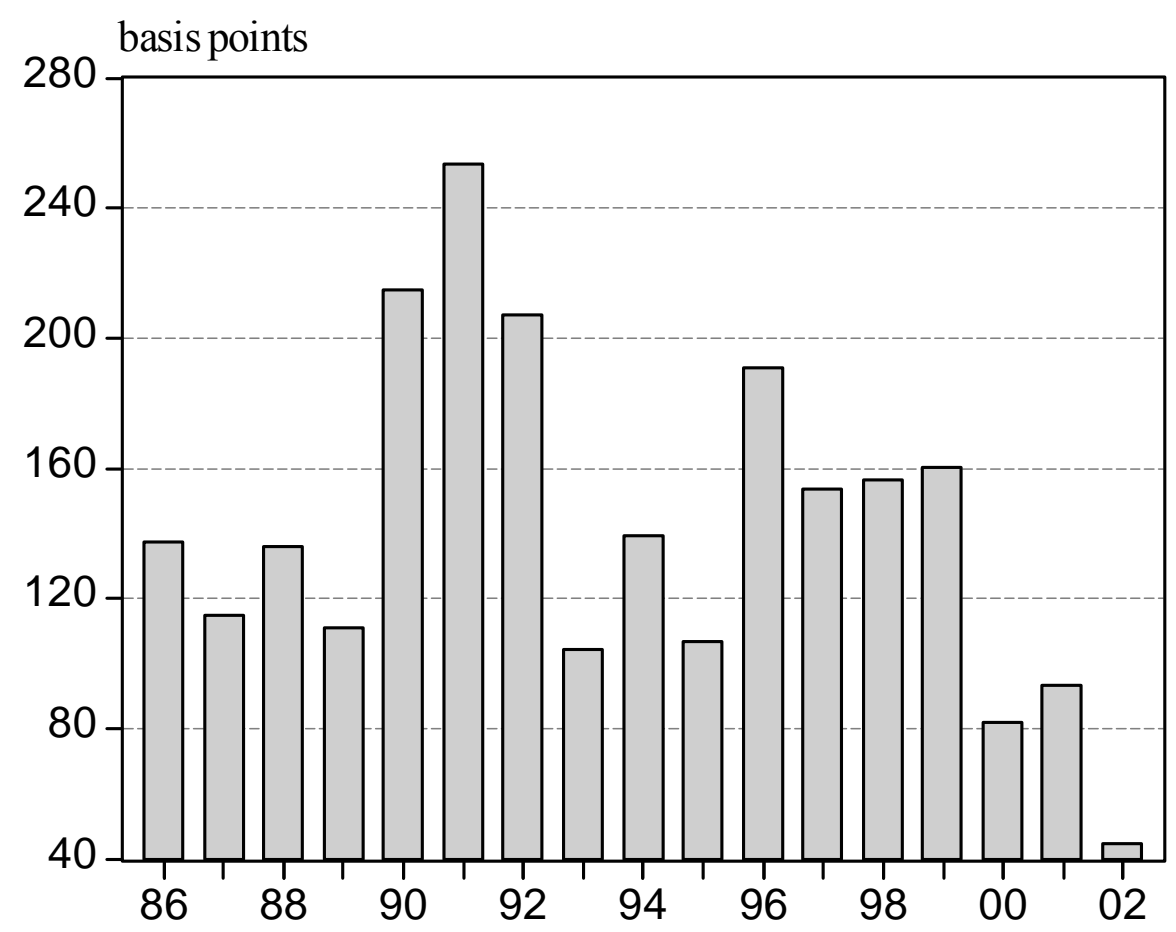

Average Intraday Standard Deviation

basis points

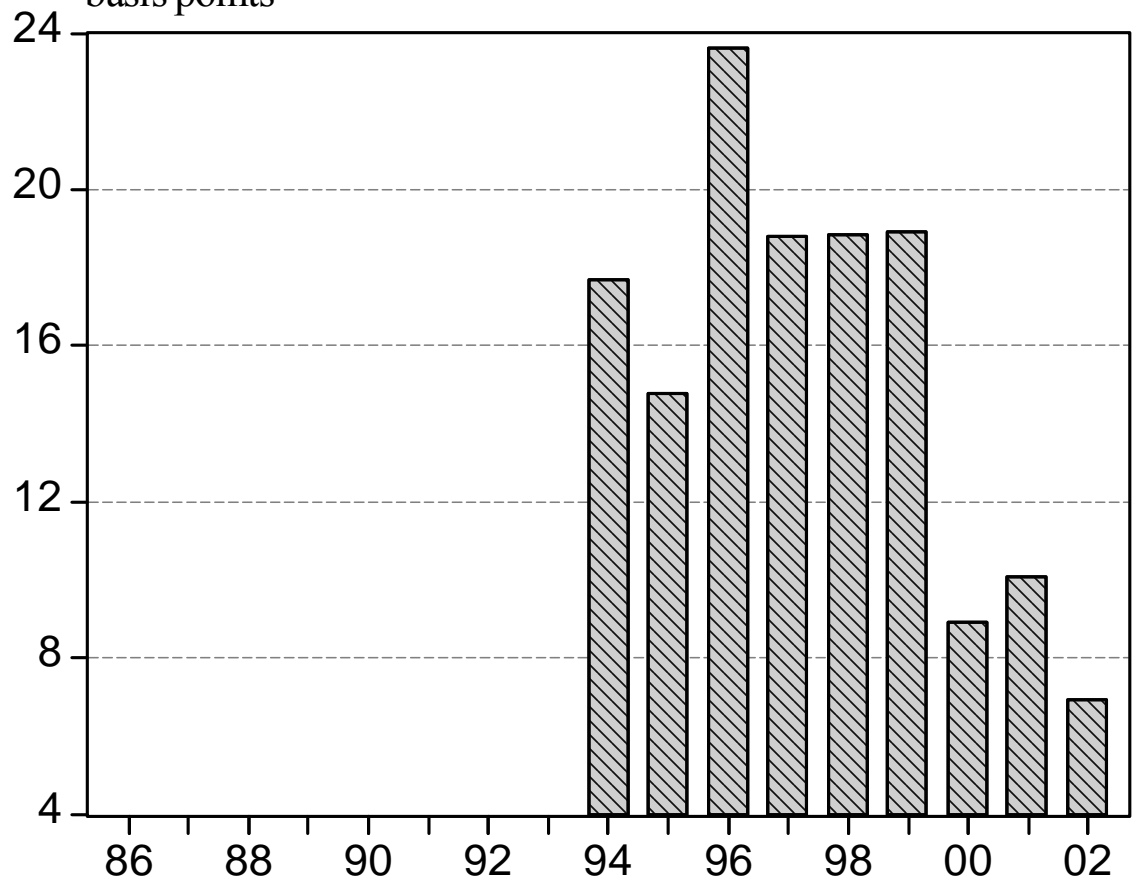




\section{References}

Akhtar, M.A. (1997), Understanding Open Market Operations, Public Information Department, Federal Reserve Bank of New York.

Anderson, R.G. and Rasche, R. H. (2000), "Retail Sweep Programs and Bank Reserves, 1994-1999," Federal Reserve Bank of St. Louis, working paper 2000-023A.

Bai, J. and Perron, P. (1998), "Estimating and Testing for Multiple Structural Changes in Linear Models," Econometrica, 66, 47-78.

Bartolini, L, Bertola, G. and Prati, A. (2002), "Day-to-Day Monetary Policy and the Volatility of the Federal Funds Interest Rate,” Journal of Money, Credit, and Banking, 34, pp. 137-159.

Bennet, P. and Peristani, S. (2002), “Are U.S. Reserve Requirements Still Binding?” Economic Policy Review, FRBNY, vol. 8, pp. 53-68.

Federal Reserve Bank of New York Markets Group, 2001, Annual Report, Domestic Open Market Operations During 2000.

Clouse, J.A. and Elmendorf, D.W. (1997), "Declining Required Reserves and the Volatility of the Federal Funds Rate," Finance and Economics Discussion Series Paper 1997-30.

Clouse, J. A. and Dow, J.P. (2002), “A Computational Model for Banks' Optimal Reserve Management Policy," Journal of Economic Dynamics and Control, 26, pp. 1787-1814.

Demiralp, S. and Jorda, O. (2002), “The Announcement Effect: Evidence from Open Market Desk Data," Economic Policy Review, FRBNY, vol. 8, pp. 29-48.

Demiralp, S. and Jorda, O. (2003), “The Response of Term Rates to Fed Announcements," Journal of Money, Credit, and Banking, forthcoming.

Edwards, C. L. (1997), "Open Market Operations in the 1990s," Federal Reserve Bulletin, November.

Feinman, J.(1993), "Estimating the Open Market Desk's Daily Reaction Function," Journal of Money, Credit, and Banking, Vol. 25, No 2.

Furfine, C. H.(2000), "Interbank Payments and the Daily Federal Funds Rate," Journal of Monetary Economics, 46, 535-553.

Hamilton, J. D. (1996), “The Daily Market for Federal Funds,” Journal of Political Economy, 104, 2656.

Hilton, S. (2003), "Structuring Short-Term RPs in the Total Financial Portfolio of the Federal Reserve," Federal Reserve Bank of New York, unpublished manuscript. 
Judge, G., Hill, R.C., Griffiths, W.E., Lukepohl, H. and Lee, T. (1988), Introduction to the Theory and Practice of Econometrics, $2^{\text {nd }}$ ed, John Wiley and Sons, Inc.

Meulendyke, A. M. (1998), U.S Monetary Policy and Financial Markets, Federal Reserve Bank of New York.

Sellon, G. and Weiner, S. (1996), "Monetary Policy Without Reserve Requirements: Analytical Issues," Economic Review, Federal Reserve Bank of Kansas City, Q4, pp.5-24

Sellon, G. and Weiner, S. (1997), "Monetary Policy Without Reserve Requirements: Case Studies and Options for the United States," Economic Review, Federal Reserve Bank of Kansas City, Q2, pp.5-30

Whitesell, W., Demiralp, S., and Preslopsky, B. (2003), "Brokered Fed Funds and Other Overnight Loans," Board of Governors of the Federal Reserve System, unpublished manuscript. 